\title{
PENGEMBANGAN SISTEM PAKAR PENDETEKSI PENYAKIT PADA KUCING DENGAN METODE CASE BASED REASONING DAN CERTAINTY FACTOR BERBASIS ANDROID
}

\author{
Galuh Gupita $^{1}$, Budi Harijanto ${ }^{2}$, Yuri Ariyanto ${ }^{3}$ \\ Program Studi Teknik Informatika, Jurusan Teknologi Informasi, Politeknik Negeri Malang. \\ .ggupita@gmail.com, ${ }^{2}$.budi.hijet@gmail.com, ${ }^{3}$-yuri.bjn@gmail.com
}

\begin{abstract}
Abstrak
Penyakit pada kucing, seringkali membuat pemiliknya merasa bingung karena kurangnya pengetahuan pemilik tentang penyakit binatang tersebut. Permasalahan yang sering terjadi antara lain ketidaktahuan masyarakat tentang informasi dalam diagnosa dan penanganan penyakit pada binatang kucing, serta terkadang sulit untuk menemui seorang ahli/pakar dalam keadaan mendesak.

Oleh karena itu dalam penelitian ini membuat Sistem pakar yang mampu melakukan diagnosa penyakit pada kucing dengan melihat gejala-gejala yang ada pada kucing yang sedang sakit sistem pakar ini juga berguna untuk membantu para pemilik kucing agar dapat mengetahui, mengerti dan memahami jenis penyakit pada kucing yang dipelihara.

Dengan adanya sistem pakar ini para pemilik kucing dapat memperoleh informasi mengenai penyakit pada kucing beserta solusinya dengan mudah, cepat dan tepat. Hasil pada sistem yang dibuat, inputan gejala yang berbeda-beda meskipun gejala yang diinputkan tersebut masih dalam satu penyakit memiliki nilai kepastian (Certainty Factor) dan kemiripan (Similarity) yang berbeda. Secara garis besar, bila gejala yang diinputkan semakin banyak yang sama maka nilai atau hasil semakin tinggi, hasil bisa $90 \%$ jika gejala yang diinputkan merupakan suatu gejala yang khas dari suatu penyakit.
\end{abstract}

Kata kunci : Kucing, Android, Certainty Factor, Case Based Reasoning.

\section{Pendahuluan \\ 1.1 Latar Belakang}

Kucing merupakan binatang yang banyak dipelihara oleh sebagian masyarakat selain itu kucing bisa dimanfaatkan sebagai sahabat bagi pemiliknya. Walaupun kucing yang dipelihara oleh manusia selalu berada didalam rumah, tidak menutup kemungkinan kucing yang dipelihara tersebut terserang penyakit, baik itu penyakit yang bisa dilihat secara kasat mata maupun penyakit pada organ dalam. Penyakit pada binatang kucing, seringkali membuat pemiliknya merasa bingung karena kurangnya pengetahuan pemilik tentang penyakit binatang tersebut. Permasalahan yang sering terjadi antara lain ketidaktahuan masyarakat tentang informasi dalam diagnosa dan penanganan penyakit pada binatang kucing, serta terkadang sulit untuk menemui seorang ahli/pakar dalam keadaan mendesak, dan mahalnya biaya untuk seorang ahli/pakar juga menjadi salah satu latar belakang malasnya mereka membawa kucing peliharaan mereka ke pakar/dokter hewan.

Berawal dari permasalahan tersebut, dalam penelitian ini akan membuat Sistem pakar yang mampu melakukan diagnosa penyakit pada kucing dengan melihat gejala-gejala yang ada pada kucing yang sedang sakit sistem pakar ini juga berguna untuk membantu para pemilik kucing agar dapat mengetahui, mengerti dan memahami jenis penyakit pada kucing yang dipelihara. Aplikasi Sistem pakar ini juga dapat mengetahui penanganan pertolongan pertama pada kucing yang sedang sakit.

Sistem pakar yang akan dibuat menggunakan metode Case Based Reasoning (CBR) digunkan untuk mencari nilai kemiripan penyakit dengan kasus terdahulu dan Certainty Factor untuk mencari nilai kepastian penyakit dengan menghitung nilai probabilitas gejala pada penyakit. Sistem akan menghasilkan keluaran yang berupa diagnosa penyakit yang dialami kucing, gejala-gejala yang sudah dipilih oleh user, dan juga memberi solusi cara pencegahan penyakit pertolongan pertama penyakit berdasarkan hasil input gejala yang dilakukan oleh user.

Sistem pakar yang akan dibuat berbasis android, karena masyarakat saat ini sudah tidak asing lagi dengan yang namanya smartphone, hampir setiap orang memiliki smartphone dari anak - anak hingga dewasa dan smartphone sangat sering digunakan untuk mencari informasi dari pada 
menggunakan PC atau laptop. Oleh karena itu dalam penelitian ini sistem pakar dibuat dengan menggunakan platform android untuk memudahkan pemilik kucing dalam mendiagnosa penyakit kucing dengan mudah dan dapat diakses dimanapun.

\subsection{Rumusan Masalah}

a. Bagaimana mengimplementasikan metode case based reasoning dan metode certainty factor ke dalam sistem pakar dibuat, sehingga sistem pakar ini dapat membantu dalam memberikan informasi dan solusi dengan mudah?

b. Bagaimana memudahkan para pemilik kucing dalam mendiagnosa dan menangani penyakit pada kucing peliharaannya ?

\subsection{Batasan Masalah}

1. Data diperoleh dari seorang pakar dan buku.

2. Sistem pakar ini hanya untuk diagnosa penyakit pada kucing.

3. Sistem pakar ini membatasi hanya untuk mendiagnosa 20 penyakit pada kucing.

4. Proses penentuan diagnosa penyakit diambil berdasarkan gejala-gejala yang dialami oleh kucing peliharaan kemudian diinputkan oleh pemilik kucing.

\section{Landasan Teori}

\subsection{Sistem Pakar}

Sistem pakar adalah suatu program komputer yang dirancang untuk mengambil keputusan seperti keputusan yang diambil oleh seorang atau beberapa orang pakar. Menurut Marimin (1992), sistem pakar adalah sistem perangkat lunak komputer yang menggunakan ilmu, fakta, dan teknik berpikir dalam pengambilan keputusan untuk menyelesaikan masalah-masalah yang biasanya hanya dapat diselesaikan oleh tenaga ahli dalam bidang yang bersangkutan.

Dalam penyusunannya, sistem pakar mengkombinasikan kaidah-kaidah penarikan kesimpulan (inference rules) dengan basis pengetahuan tertentu yang diberikan oleh satu atau lebih pakar dalam bidang tertentu. Kombinasi dari kedua hal tersebut disimpan dalam komputer, yang selanjutnya digunakan dalam proses pengambilan keputusan untuk penyelesaian masalah tertentu.

\subsection{Case Based Reasoning (CBR)}

Case based reasoning (CBR) menggunakan pendekatan kecerdasan buatan (Artificial Intelligent) yang menitik beratkan pemecahan masalah dengan didasarkan pada knowledge dari kasus - kasus sebelumnya. Secara detail CBR terbagi dalam empat tahap, yaitu:

1 Retrieve yaitu menemukan kembali kasus

yang paling mirip dengan kasus baru yang akan dievaluasi.

2 Reuse yaitu menggunakan kembali informasi atau pengetahuan yang telah tersimpan pada basis kasus untuk memecahkan masalah baru.

3 Revise yaitu memperbaiki solusi yang diusulkan.

4 Retain yaitu menyimpan pengetahuan yang nantinya akan digunakan untuk memecahkan masalah kedalam basis kasus yang ada.

\subsection{Kemiripan (Similarity)}

Kemiripan (similarity) adalah langkah yang digunakan untuk mengenali kesamaan atau kemiripan antara kasus - kasus yang tersimpan dalam basis kasus dengan kasus yang baru. .Kasus dengan nilai similarity paling besar dianggap sebagai kasus yang

"paling mirip". Nilai similarity berkisar antara 0 sampai 1. Berikut ini merupakan rumus untuk mencari nilai kemiripan ( similarity ) yaitu :

\section{Keterangan :}

$\mathrm{Ti}=$ Nilai kesamaan kasus

$\mathrm{nX} 1+\mathrm{nX} 2+\mathrm{nX} 3=$ Banyaknya kesamaan subobjek $\mathrm{X} 1, \mathrm{X} 2, \mathrm{X} 3 \ldots \mathrm{Xn}$

$\mathrm{N}=$ banyak elemen pada basis kasus.

\subsection{Certainty Factor}

Faktor kepastian (Certainty Factor) menyatakan

kepercayaan dalam sebuah kejadian (atau fakta atau hipotesis) berdasarkan bukti atau penilaian pakar. Certainty factor menggunakan suatu nilai untuk mengasumsi derajad keyakinan seorang pakar

terhadap suatu data. Certainty factor memperkenalkan konsep keyakinan dan ketidakyakinan yang kemudian diformulakan dalam rumusan dasar sebagai berikut:

$\mathrm{CF}[\mathrm{H}, \mathrm{E}]=\mathrm{MB}[\mathrm{H}, \mathrm{E}]-\mathrm{MD}[\mathrm{H}, \mathrm{E}]$

Formula dasar digunakan apabila belum ada nilai $\mathrm{CF}$ untuk setiap gejala yang menyebabkan penyakit. Kombinasi certainty factor yang digunakan untuk mengdiagnosa penyakit adalah (Turban: 2005):

1. Certainty Factor untuk kaidah dengan premis/gejala tunggal (single premis rules):

CFgejala $=\mathrm{CF}[$ user] $* \mathrm{CF}[$ pakar]

2. Apabila terdapat kaidah dengan kesimpulan yang serupa (similiary concluded rules) atau lebih dari satu gejala, maka CF selanjutnya dihitung dengan persamaan:

CFcombine $=$ CFold + CFgejala $*(1-$ CFold $)$ 


\section{Metodologi \\ 3.1 Desain Penelitian}

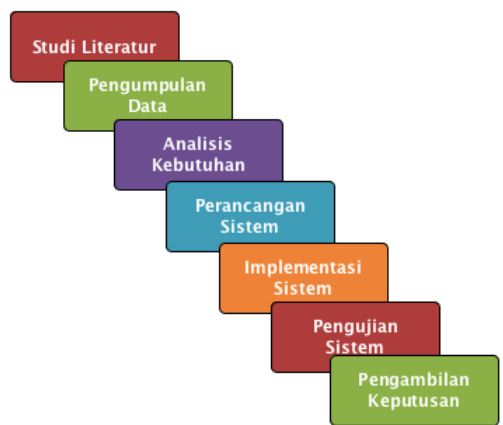

Gambar 1 Diagram Blok Penelitian

4. Perancangan

\subsection{Contoh Kasus}

Tabel 1. kasus lama

\begin{tabular}{|c|c|c|}
\hline Kode Penyakit & Nama Penyakit & Gejala \\
\hline P012 & Salmonella & G045, G046, \\
& & G012, G047, \\
& & G048, G004, \\
& & G014, G005 \\
\hline
\end{tabular}

Tabel 2. Tabel yang dipilih user / pasien

\begin{tabular}{|l|l|}
\hline $\begin{array}{c}\text { Inputan } \\
\text { konsultasi }\end{array}$ & Gejala yang di inputkan oleh user \\
\hline 1 & G045, G047, G004, G005 \\
\hline 2 & $\begin{array}{l}\text { G045, G047, G048, G004, } \\
\text { G014, G005 }\end{array}$ \\
\hline
\end{tabular}

Setelah pasien / user menginputkan gejala yang dikeluhkan atau telah melakukan proses retrieve, kemudian sistem akan melakukan proses tahapan yang kedua yakni proses reuse, yang mana dalam proses ini dilakukan proses penelusuran penyakit, perhitungan similarity (nilai kemiripan) dan perhitung certainty factor antara kasus lama dengan kasus baru. Dalam kasus ini pasien / user melakukan dua kali proses konsultasi. Konsultasi pertama menginputkan gejala G045, G047, G004, G005, dan konsultasi kedua menginputkan G045, G047, G048, G004, G014, G005.

a. Konsultasi user pertama

1. Perhitungan nilai kemiripan (Similarity)

Tabel di bawah merupakan tabel perbandingan gejala penyakit Salmonella pada kasus lama dan kasus baru.

Tabel 3. Tabel Gejala Penyakit Salmonella 1

\begin{tabular}{|c|c|c|c|c|}
\hline \multicolumn{2}{|c|}{ Salmonella } & \multirow[b]{2}{*}{$\begin{array}{l}\text { Similarity } \\
\text { coeffisien }\end{array}$} & \multirow[b]{2}{*}{ CFpakar } & \multirow[b]{2}{*}{ CFuser } \\
\hline $\begin{array}{c}\text { Kode } \\
\text { Gejala } \\
\text { Kasus } \\
\text { Lama }\end{array}$ & $\begin{array}{l}\text { Kode } \\
\text { Gejala } \\
\text { Kasus } \\
\text { Baru } \\
\end{array}$ & & & \\
\hline G045 & G045 & 1 & 0.9 & 0.8 \\
\hline G046 & - & 0 & 0.9 & 0 \\
\hline G012 & - & 0 & 0.4 & 0 \\
\hline G047 & G047 & 1 & 0.6 & 0.4 \\
\hline G048 & - & 0 & 0.4 & 0 \\
\hline
\end{tabular}

\begin{tabular}{|c|c|c|c|c|}
\hline $\begin{array}{l}\text { G004 } \\
\text { G014 } \\
\text { G005 }\end{array}$ & $\begin{array}{l}\text { G004 } \\
- \\
\text { G005 }\end{array}$ & $\begin{array}{l}1 \\
0 \\
1\end{array}$ & $\begin{array}{l}0.4 \\
0.4 \\
0.4\end{array}$ & $\begin{array}{l}1 \\
0 \\
0.6\end{array}$ \\
\hline
\end{tabular}

2. Perhitungan Nilai Kepastian (Certainty Factor)

Dari gejala yang telah dipilih muncul rules dari gejala-gejala tersebut, yaitu:

Rule :

IF G045 dengan CFpakar $=0.9$ dan CFuser $=0.8$

AND G047 dengan CFpakar $=0.6$ dan CFuser $=0.4$

AND G004 dengan CFpakar $=0.4$ dan CFuser $=0.1$

AND G005 dengan CFpakar $=0.4$ dan CFuser $=0.6$

THEN Salmonella

Dari rules diatas, rule yang memiliki gejala majemuk, akan dipecah menjadi rule yang memiliki gejala tunggal.

Rule 1.1 : IF G045 dengan CFpakar $=0.9$ dan CFuser $=0.8$

THEN Salmonella

Rule 1.2 : IF G047 dengan CFpakar $=0.6$ dan CFuser $=0.4$

THEN Salmonella

Rule 1.3 : IF G004 dengan CFpakar $=0.4$ dan CFuser $=1$

THEN Salmonella

Rule 1.4 : IF G005 dengan CFpakar $=0.4$ dan CFuser $=0.6$

THEN Salmonella

Setelah rule tunggal terbentuk lalu menghitung nilai kepercayaannya. Perhitungan dimulai dengan menghitung CFpakar dengan CFuser dengan menggunakan persamaan: $\mathrm{CF}(\mathrm{H}, \mathrm{E})=\mathrm{CFuser} *$ CFpakar menjadi:

$\begin{array}{rrrrl}\text { CF } 1.1 & 0.8 & * & 0.9 & =0.72 \\ \text { CF } 1.2 & 0.4 & * & 0.6 & =0.24 \\ \text { CF } 1.3 & 1 & * & 0.4 & =0.4 \\ \text { CF } 1.4 & 0.6 & * & 0.4 & =0.24\end{array}$

Setelah itu mengkombinasikan CF tersebut kedalam $\mathrm{CF}$ kombinasi dengan rumus: CFkombinasi = $\mathrm{CF}(\mathrm{R} 1)+\mathrm{CF}(\mathrm{R} 2) *(1-\mathrm{CF}(\mathrm{R} 1))$. Perhitungan $\mathrm{CF}$ kombinasi setiap penyakit adalah sebagai berikut: 


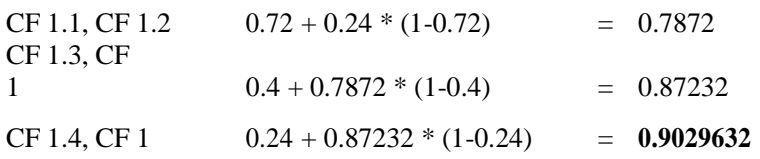

$=0.9029632$

Hasil konsultasi user dengan gejala yang diinputkan pada proses diagnosa yang pertama menghasilkan nilai kemiripan sebesar 0.52 dan nilai kepastian sebesar 0.9029632

b. Konsultasi user kedua

1. Perhitungan nilai kemiripan (Similarity)

Tabel di bawah merupakan tabel perbandingan gejala penyakit Salmonella pada kasus lama dan kasus baru

Tabel 3. Tabel Gejala Penyakit Salmonella 2

\begin{tabular}{|c|c|c|c|c|}
\hline \multicolumn{2}{|c|}{ Salmonella } & \multirow[b]{2}{*}{$\begin{array}{l}\text { Similarity } \\
\text { coeffisien }\end{array}$} & \multirow[b]{2}{*}{ CFpakar } & \multirow[b]{2}{*}{ CFuser } \\
\hline $\begin{array}{l}\text { Kode } \\
\text { Gejala } \\
\text { Kasus } \\
\text { Lama }\end{array}$ & $\begin{array}{l}\text { Kode } \\
\text { Gejala } \\
\text { Kasus } \\
\text { Baru }\end{array}$ & & & \\
\hline G045 & G045 & 1 & 0.9 & 0.8 \\
\hline G046 & - & 0 & 0.9 & 0 \\
\hline G012 & - & 0 & 0.4 & 0 \\
\hline G047 & G047 & 1 & 0.6 & 0.4 \\
\hline G048 & G048 & 1 & 0.4 & 1 \\
\hline G004 & G004 & 1 & 0.4 & 1 \\
\hline G014 & G014 & 1 & 0.4 & 1 \\
\hline G005 & G005 & 1 & 0.4 & 0.6 \\
\hline
\end{tabular}

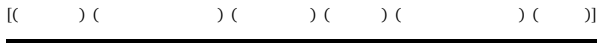

2. Perhitungan Nilai Kepastian (Certainty Factor)

Dari gejala yang telah dipilih muncul rules dari gejala-gejala tersebut, yaitu:

Rule :

IF G045 dengan CFpakar $=0.9$ dan CFuser $=0.8$

AND G047 dengan CFpakar $=0.6$ dan CFuser $=0.4$

AND G048 dengan CFpakar $=0.4$ dan CFuser $=1$

AND G004 dengan CFpakar $=0.4$ dan CFuser $=1$

AND G014 dengan CFpakar $=0.4$ dan CFuser $=1$

AND G005 dengan CFpakar $=0.4$ dan CFuser $=0.6$

THEN Salmonella

Dari rules diatas, rule yang memiliki gejala majemuk, akan dipecah menjadi rule yang memiliki gejala tunggal.

Rule 1.1 : IF G045 dengan CFpakar $=0.9$ dan CFuser $=0.8$

THEN Salmonella

Rule 1.2 : IF G047 dengan CFpakar = 0.6 dan CFuser $=0.4$

THEN Salmonella

Rule 1.3 : IF G048 dengan CFpakar $=0.4$ dan CFuser $=1$

THEN Salmonella

Rule 1.4 : IF G004 dengan CFpakar $=0.4$ dan CFuser $=1$

THEN Salmonella

Rule 1.5 : IF G014 dengan CFpakar $=0.4$ dan CFuser $=1$

THEN Salmonella

Rule 1.6 : IF G005 dengan CFpakar $=0.4$ dan CFuser $=0.6$

THEN Salmonella

Setelah rule tunggal terbentuk lalu menghitung nilai kepercayaannya. Perhitungan dimulai dengan menghitung CFpakar dengan CFuser dengan menggunakan persamaan: $\mathrm{CF}(\mathrm{H}, \mathrm{E})$ $=$ CFuser $*$ CFpakar menjadi:

$\begin{array}{lrll}\text { CF } 1.1 & 0.8 & * & 0.9=0.72 \\ \text { CF 1.2 } & 0.4 & * & 0.6=0.24 \\ \text { CF 1.3 } & 1 & * & 0.4=0.4 \\ \text { CF } 1.4 & 1 & * & 0.4=0.4 \\ \text { CF } 1.5 & 1 & * & 0.4=0.4 \\ \text { CF } 1.6 & 0.6 & * & 0.4=0.24\end{array}$

Setelah itu mengkombinasikan CF tersebut kedalam CF kombinasi dengan rumus: CFkombinasi $=\mathrm{CF}(\mathrm{R} 1)+\mathrm{CF}(\mathrm{R} 2) *(1-\mathrm{CF}(\mathrm{R} 1))$. Perhitungan $\mathrm{CF}$ kombinasi setiap penyakit adalah sebagai berikut:

\begin{tabular}{|c|c|c|}
\hline CF $1.1, \mathrm{CF}$ & & \\
\hline 1.2 & $0.72+0.24 *(1-0.72)$ & $=0.7872$ \\
\hline CF $1.3, \mathrm{CF}$ & & \\
\hline 1old & $0.4+0.7872 *(1-0.4)$ & $=0.87232$ \\
\hline CF $1.4, \mathrm{CF}$ & & \\
\hline 1old1 & $0.4+0.87232 *(1-0.4)$ & $=0.923392$ \\
\hline $\mathrm{CF} 1.5, \mathrm{CF}$ & & \\
\hline 1old1 & $0.4+923392 *(1-0.4)$ & $=0.9540352$ \\
\hline CF 1.6, CF & $0.24+0.9540352 *(1-$ & \\
\hline 1old1 & $0.4)$ & $=0.965066752$ \\
\hline
\end{tabular}

Hasil konsultasi user dengan gejala yang diinputkan pada proses diagnosa yang pertama menghasilkan nilai kemiripan sebesar 0.7 dan nilai kepastian sebesar 0.965066752

Pada tabel di bawah ini memuat tentang perbandingan nilai kepastian penyakit yang dihitung dengan merode Certainty Factor dan nilai kemiripan yang dihitung dengan Similarity 
berdasarkan gejala yang diinputkan untuk setiap melakukan konsultasi.

Tabel 5. Perbandingan hasil nilai kepastian dan nilai kemiripan

\begin{tabular}{|c|c|l|c|c|}
\hline in & Gejala & $\begin{array}{l}\text { Certainty } \\
\text { Factor }\end{array}$ & $\begin{array}{c}\text { Similar } \\
\text { ity }\end{array}$ & Penyakit \\
\hline 1 & $\begin{array}{l}\text { G045, G047, } \\
\text { G004, G005 }\end{array}$ & 0.9029632 & 0.52 & \multirow{2}{*}{ Salmonella } \\
\hline 2 & $\begin{array}{l}\text { G045, G047, } \\
\text { G048, G004, } \\
\text { G014, G005 }\end{array}$ & 0.965066752 & 0.7 & \\
\hline
\end{tabular}

Dari tabel hasil konsultasi pasien/ user diatas, dapat disimpulkan bahwa dengan inputan gejala yang berbeda-beda meskipun gejala yang diinputkan tersebut masih dalam satu penyakit memiliki nilai kepastian (Certainty Factor) dan kemiripan (Similarity) yang berbeda. Secara garis besar, bila gejala yang diinputkan semakin banyak yang sama maka nilai atau hasil semakin tinggi.

\section{Implementasi \\ a. Tampilan Pilihan Gejala}

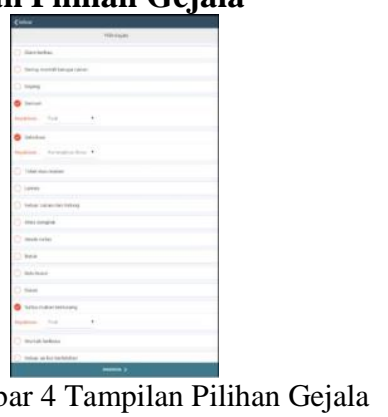

b. Tampilan Hasil Diagnosa

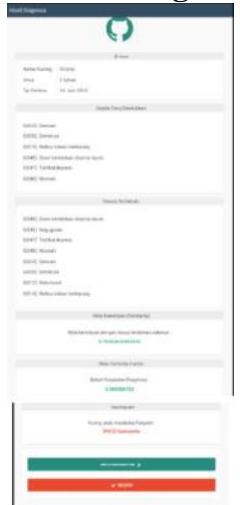

Gambar 4 Tampilan Hasil Diagnosa

\section{Uji Coba Dan Pembahasan \\ 6.1 Pengujian}

Tabel 6. Tabel pengujian

\begin{tabular}{|c|c|c|c|}
\hline \multirow{2}{*}{ No } & \multirow{2}{*}{$\begin{array}{c}\text { Inputan } \\
\text { Gejala }\end{array}$} & \multicolumn{2}{|c|}{ Hasil Diagnosis } \\
\hline & & Excel & Sistem \\
\hline 1. & $\begin{array}{l}\text { - Demam } \\
\text { - Dehidrasi } \\
\text { - Diare } \\
\text { berlebih } \\
\text { disertai } \\
\text { darah } \\
\text { - Terlihat } \\
\text { depresi } \\
\end{array}$ & Salmonella & Salmonella \\
\hline 2. & $\begin{array}{l}\text { - Diare } \\
\text { berbau } \\
\text { - Demam } \\
\text { - Dehidrasi }\end{array}$ & Distemper & Distemper \\
\hline
\end{tabular}

\section{Kesimpulan Dan Saran}

7.1 Kesimpulan

a. Penerapan metode Certainty Factor $(C F)$ dan Case Based Reasonig (CBR) untuk membangun suatu sistem pakar untuk diagnosa penyakit pada kucing berdasarkan pada beberapa fakta dan gejala.

b. Sistem yang dibuat bisa mendeteksi penyakit berdasarkan gejala yang disampaikan saat melakukan proses diagnosa.

c. Sistem yang dibuat memiliki fasilitas informasi mengenai penyakit kucing.

\subsection{Saran}

Saran yang diberikan untuk pengembangan sistem dalam penelitian selanjutnya adalah:

a. Data pada sistem seharusnya selalu di-update oleh admin secara berkala sesuai dengan perkembangan yang berkaitan dengan sistem.

\section{Daftar Pustaka:}

Burhani, Ananda Ayu Zahara. 2014. Sistem Pakar Diagnosis Penyakit Pada Kelinci Menggunakan Metode Certainty Factor. Program Studi Teknik Informatika, Jurusan Teknik Elektro, Politeknik Negeri Malang.

Elsa, F dan Graham, M., 2013. Buku Pintar Pemilik

Kucing (The cat owner's handbook), Tangerang; Karisma.

Prayogo, Y, 2013. Cat Lover's Book Segala hal yang perlu kamu ketahui untuk merawat kucing,

Jakarta Selatan; GagasMedia.

Sri Winiarti dan Faza Akmal (2014), Sistem Pakar Untuk Mendiagnosa Penyakit Lambung Dengan Implementasi Metode Cbr (CaseBased Reasoning) Berbasis Web, Volume 2 
Nomor 1, Februari 2014, Program Studi

Teknik Informatika Universitas Ahmad

Dahlan [14 Mei 2016] 